\title{
Marine Birds as Sentinels of Environmental Pollution
}

\author{
Joanna Burger $^{1}$ and Michael Gochfeld ${ }^{2}$ \\ ${ }^{1}$ Division of Life Sciences, Rutgers University, 604 Allison Road, Piscataway, NJ 08854-8082 \\ ${ }^{2}$ Environmental and Community Medicine, University of Medicine and Dentistry of New Jersey-Robert Wood Johnson Medical School, Piscataway, \\ NJ 08854
}

\begin{abstract}
Marine birds are useful as bioindicators of environmental pollution in estuarine and marine environments because they are often at the top of the food chain, ubiquitous, and many are abundant and common, making collecting possible. Seabirds have the advantage of being large, wide-ranging, conspicuous, abundant, long-lived, easily observed, and important to people. Many species are at the top of the food chain where they bioaccumulate contaminants with age. One disadvantage is that many species are migratory, making it difficult to determine where exposure occurred. This can be eliminated by using sedentary species or young birds that obtain all their food from parents. Further, noninvasive collection of feathers can be used to assess heavy metal levels, both from current collections and from historical collections in museums dating back centuries. Marine birds can be used as bioindicators in many ways, including tissue levels of contaminants, epidemiological field studies of effects, and experimental and laboratory studies of dose and effects. Examples from our research indicate some of the ways marine birds can be useful as indicators and sentinels of contamination, particularly by using young birds and feathers.
\end{abstract}

Key words: pollution, indicators, sentinel species, ecosystem health, heavy metals, feathers, seabirds, mercury, cadmium lead

\section{INTRODUCTION}

Increasingly, governments, managers, conservationists, and the general public are concerned about the health of the environment, and require indicators that assess status and trends. The use of chemicals is increasing daily in industries, farms, and homes. Aquatic environments are particularly vulnerable because of the rapid movement of contaminants in water, compared to movement in terrestrial environments. Levels of many of these chemicals are elevated in marine and coastal ecosystems because of the

Published online: May 28, 2004

Correspondence to: Joanna Burger, e-mail: burger@biology.rutgers.edu influx from rivers, as well as runoff and direct pollution (Furness and Rainbow, 1990). While there are still threats from local point source polluters such as industries and sewage outfalls, there continue to be nonpoint sources of concern. Particularly with growing populations, energy demands, and industrialization, the threat from long-range atmospheric transport and deposition of certain substances is increasing as many chemicals, such as mercury, are transported to all regions, including the Arctic and the Antarctic (Houghton et al., 1992; Fitzgerald, 1989).

In this article, we explore the use of marine birds as bioindicators and sentinels of the fate and effects of pollutants in our estuaries and oceans. We examine the advantages and disadvantages of using marine birds as 
sentinel species for both ecological and human health effects, applied methodologies, examples of marine birds as sentinels, and future research needs to improve their utilization.

Seabirds are useful as bioindicators of coastal and marine pollution (Hays and Risebrough, 1972; Gochfeld, 1980; Walsh, 1990; Peakall, 1992; Furness, 1993; Furness and Camphuysen, 1997). Marine birds, defined as birds that spend a significant proportion of their life in coastal or marine environments, are exposed to a wide range of chemicals because most occupy higher trophic levels making them susceptible to bioaccumulation of pollutants. Since different families of seabirds, and different species within these families, have different life history strategies and cycles, behavior and physiology, diet, and habitat uses, their vulnerability varies (Burger and Gochfeld, 2001a). Further, the relative proportion of time marine birds spend near shore, compared to pelagic environments, influences their exposure. As with other animals, susceptibility often varies with age, reproductive stage, and gender (Burger, 1993).

The effects of pollutants on marine birds, as in other organisms, are the result of exposure, which can be acute or chronic. Acute exposure to a contaminant will have a different impact from chronic intake of small quantities, even when the same total dose is achieved. Means of exposure include inhalation, ingestion, dermal, and injection (Burger and Gochfeld, 2000a, 2001a). For marine birds, ingestion of food and water are the main routes of exposure.

The dose delivered to the target organ is a function of the pathway from source, environmental fate and transport, food chain bioaccumulation, contact, intake, bioavailability, absorption, metabolism, transport and excretion, and distribution within the body. Bioaccumulation refers to both the uptake of dissolved chemicals from water (=bioconcentration) and uptake from ingested food and sediment residues. A bioaccumulation factor is the ratio between the concentration in the organism and the concentration in the medium. Biomagnification is the increase in the concentration as one goes from a lower to a higher trophic level (Burger, 2002). Each step in this process involves a bioaccumulation factor greater than one. All of these aspects require careful study and experimentation to determine the effect of a given pollutant on an organism.

The major groups of pollutants of concern are pesticides, chlorinated hydrocarbons, metals, and petroleum products (particularly polyaromatic hydrocarbons). Recently, attention has focused on a much wider range of industrial and agricultural compounds which may be bioactive, including those that interact with the endocrine system or have hormone-like effects (NRC, 1999).

\section{Marine Birds as Sentinels}

A few groups of animals dominate the contaminant literature, including crustaceans, fish, and birds, particularly raptors, waterfowl, and seabirds (Burger, 1993; Furness, 1993; Hoffman et al., 1996; Beyer et al., 1996). Seabirds are advantageous as sentinel species because they are diurnal, large, wide-ranging, conspicuous, abundant, long-lived, easily observed and monitored, and are of interest to the public (Table 1). Many species are at the top of the food chain where they can be exposed to relatively high levels of contaminants in their prey (Monteiro and Furness, 1995). Since many species of seabirds return to the same nest and colony sites for years, contaminant loads of individuals can be studied over time (Burger, 1993). Although some seabird populations are threatened or endangered through habitat loss, exploitation, overfishing, and other anthropogenic impacts (Croxall et al., 1984), populations of most species are not threatened, and the collecting of limited individuals does not pose a conservation problem. Further, since marine birds often nest in mixed species colonies, there are usually one or two species whose populations are robust enough to allow collection, thereby serving as sentinels for the entire community.

Birds integrate contamination over time and space (Walsh, 1990; Burger, 1993). Many seabirds travel over substantial distances to obtain food, thus sampling prey from different regions. The resultant levels in their tissues are an indication of contamination over that area. Seabirds are sentinels for local, regional, and global scales, and have proven particularly useful as bioindicators for contamination in the Great Lakes (Fox, 1976; Mineau et al., 1984; Weseloh et al., 1995; Pekarik and Weseloh, 1998).

Sampling contaminants in vertebrate tissues, particularly seabird tissues, is often more cost-effective than sampling water, pore water, sediment, or invertebrates, because those samples represent only the small number of points. To sample a large bay or estuary using water or sediments, many points are required to obtain a picture of pollutant levels, with serial specimens needed to capture seasonal fluctuations. By sampling only a few individuals, however, it is possible to determine whether there is a problem throughout the bay. Seabirds can be easily mon- 
Table 1. Advantages and Disadvantages of Using Seabirds as Sentinels of Ecosystem Health

\section{Advantages}

Top predators-high on the food chain, resulting in

biomagnification

Long-lived-time for bioaccumulation

Philopatric—allows for resampling of individuals

from year to year

Often colonial-large sample size concentrated in one place

Widespread distribution

Conspicuous-easy to find for sampling

Large in size-do not require compositing

Many species are abundant

Integrate over time and space

Mixed-species colonies often provide different trophic levels with foraging ranges

Some species are sedentary

Disadvantages

Gather food over large area-adults do not reflect point source

Most species are migratory-difficult to know location of exposure

Need to understand molt and migration patterns

Some species are threatened or endangered-too few to collect

itored visually, as well as with other methods. Radiotelemetry and satellite tracking are increasingly popular. If a problem is identified, then more extensive sampling is required to determine whether it is from a point source, of from a nonpoint source.

Using seabirds to integrate contaminant information over space and time may represent a disadvantage because of their life histories. If high levels of any contaminant are discovered, then it is necessary to understand the life cycle, molt cycle, migratory routes, prey base, foraging range, and habitat of the particular species. Knowing contaminant loads in an adult seabird will not normally identify the exact location of point-source pollution; further sampling of other bioindicators is required. It is also important to understand the migratory behavior of seabirds before interpreting contaminant levels. Sedentary species reflect local levels of pollution and are ideal as sentinels, but migratory species require an understanding of how long they have been in the local area prior to sampling. Further, some of the species that might be of interest for conservation reasons may be sufficiently vulnerable, making collection difficult.

Using eggs or feathers of fledglings to monitor contaminant levels can ameliorate many of the disadvantages discussed above. Young birds that have not yet fledged have obtained all of their food from their parents who, in most cases, obtained it from the local area. Many terns, for example, fish within a few kilometers of the breeding site. On the contrary, some albatrosses and petrels regularly travel several $100 \mathrm{~km}$ to obtain their prey making interpretation more difficult (Fisher and Fisher, 1969; Weimerskirch, 1997).

Finally, marine birds are useful as sentinels of the health of marine and coastal communities and ecosystems, including human exposure (Burger and Gochfeld, 2001b). In selecting sentinel species, it is important to identify those that provide an early warning indicator to monitor both the effects on seabirds and consequences on marine communities and humans. Selecting sentinels that can be useful for both assessing ecological and human health has the advantage that people will be most interested and likely to continue funding such programs (Burger and Gochfeld, 1996a, 2001b). Sentinels most useful for providing early warning indicators are those that consume similar prey or those that can monitor health at several different levels of biological organization from individuals, populations, through communities, ecosystems, and landscapes (Burger and Gochfeld, 2001b).

\section{Methodologies Applied to Marine Birds as Sentinels}

Information regarding environmental contaminants in seabirds can be collected by monitoring contaminant levels in individual seabirds of one population and conducting studies of effects of contaminants on individuals.

\section{Sentinel Populations}

Seabirds have often served as sentinels of environmental pollution. A classic example is dichloro-diphenyl-trichloroethane (DDT) pollution in the early 1960s when populations of some fish-eating birds sharply declined. There were severe population declines of brown pelicans (Pelecanus occidentalis) in Louisiana (Blus et al., 1979), and of pelicans, double-breasted cormorants (Phalacrocorax phalacrocorax), and other species in southern California (Anderson and Gress, 1983; Risebrough, 1986). More recently, population declines and behavioral abnormalities have provided early warning of the potential harm from endocrine disruptors (Fry et al., 1987; Fox, 1992). Bio- 
monitoring of reproductive success can sometimes indicate populations that are in jeopardy, providing warning of impending population declines, as has happened with least terns (Sterna antillarum) in the New York bight (Burger et al., 1994). Further, these early warning systems of potential endocrine disruption in seabirds focused attention on potential effects on humans.

\section{Tissue Concentrations}

Since many of the contaminants discussed in this article are lipophylic and stored in tissues, tissue levels can be used as biomarkers of exposure and may provide information about possible effects on seabirds (Peakall, 1992; Nisbet, 1994). Tissues usually collected for contaminant studies in seabirds include blood, liver, kidney, brain, and muscle. The utility of a tissue varies with the pollutant and with the research question. Blood, for example, reflects recent exposures for many substances. Liver has become a standard tissue for contaminant testing, particularly for organics. Muscle concentrations reflect risks for predators (particularly humans who eschew organs), and brain and kidney levels indicate impacts on the marine birds.

Although monitoring concentrations of contaminants in tissues is an important method of assessing potential harm of chemicals to the organisms and to their predators or scavengers, it is not always possible to collect them due to the threatened or endangered status of the species. In this case, noninvasive techniques can be used for some pollutants, such as feather collection for heavy metals.

Feathers are useful indicators of heavy metal contamination for a variety of reasons: birds sequester heavy metals in their feathers, the proportion of the body burden that is in feathers is relatively constant for each metal, and a relatively high proportion of the body burden of certain metals is stored in the feathers (Burger, 1993). Monteiro et al. (1998) demonstrated that there is a high correlation between levels of mercury in the diet of seabirds and levels of mercury in their feathers; thus seabird feathers can be used as indicators of food-chain effects. Feathers in museum collections have proven particularly useful to examine changes in mercury levels over centuries (Berg et al., 1966; Walsh, 1990; Thompson et al., 1992). Feathers can also provide a useful biomonitoring tool to assess general environmental conditions to which other organisms, including humans, are exposed (Burger and Gochfeld, 2001b).

\section{Laboratory \\ Studies}

\section{Field}

Studies

\section{Optimum}

Figure 1. Schematic of needed research to establish the links between dose, tissue concentrations, and effects.

\section{Effects Studies}

One of the classic methods of study is to experimentally expose birds to chemicals in the laboratory, thereby determining the effects from a given dose (Eisler, 1987; Burger and Gochfeld, 1997a). Often birds are given an acute dose by injection or gavage, or chronic dose through food or water. Behavioral, physiological, reproductive, and lethal effects are then recorded. Classic studies by Heinz (1979) were able to demonstrate intergenerational effects with lead. Clinical signs of lead poisoning have been demonstrated with these laboratory studies and include drooped wings, loss of appetite, lethargy, weakness, emaciation, tremors, green feces, and impaired locomotion, balance, and depth perception (Sileo and Fefer, 1987; Eisler, 1988; Burger and Gochfeld, 1994, 1997a). Lowered reproductive success and survival were also observed (Heinz, 1979).

One of the major difficulties with studies of the fate and effects of chemicals on marine birds (as well as other organisms) is the general failure to connect all aspects from dose to tissue concentrations and effects (Fig. 1). More studies are required that examine dose to the organism, effects (behavioral, physiological, morphological, lethal), and their concentrations in tissues (Burger and Gochfeld, 2001a). Most research in this area only determines two of these three aspects.

\section{Examples of Marine Birds as Sentinels}

For over 20 years, our research program has been aimed at using seabirds as bioindicators of environmental pollution, mainly concentrating on heavy metals. Our work has included using feathers as indicators of exposure worldwide, 
feathers and other tissues as indicators of regional and local pollution, tissue levels as bioindicators of potential harm to other consumers, and effects studies in the laboratory and the field to establish the relationship between exposure, effect, and tissue levels. Below we provide examples.

\section{Effects Studies}

The levels of lead in birds in the New York Bight have been examined and subsequently used to determine the appropriate dose to examine the effects of lead on neurobehavioral development in the laboratory. These studies were aimed at determining whether there were neurobehavioral effects from the levels of lead that occur in nature, whether the effects found in the laboratory also existed in the wild, whether there was any recovery in either the field or the laboratory, and whether other metals caused similar effects. This is critical because there is abundant information on contaminants in the wild and on dose levels and effects from laboratory studies, but not on effects in laboratory studies that are associated with specific levels in tissues. Metal levels from seabirds in the wild are known, but the mechanisms of association with lethal or sublethal effects are poorly understood.

Feathers were collected from young common terns (Sterna hirundo) and herring gulls (Larus argentatus) at the time of fledging, and then young were dosed in the laboratory so that the amount of lead in the feathers equaled the levels found in feathers of young gulls in nature. This methodology assured that the study examined the effect of lead levels that young birds could obtain in nature (Burger and Gochfeld, 1994; Burger, 1995). There is usually a significant correlation between concentrations of lead in feathers and those in internal tissues, including blood; therefore the concentration of lead in feathers is a good predictor of internal dose (Burger, 1993). In the laboratory, a controlled dose was achieved by injecting lead intraperitoneally. Lead was administered from 2 to 12 days posthatching, depending upon the experiment (Burger and Gochfeld, 1997a, 2000a).

This research has shown that there are several sublethal neurobehavioral effects at lead levels that occur in nature (Burger, 1990; Burger and Gochfeld, 1997a). Lead affects a wide range of behaviors, including locomotion, balance, begging, feeding, growth, and cognitive abilities, that in turn affect survival in nature. Effects vary depending upon dose and age of exposure (Burger and Gochfeld, 1995a,b).

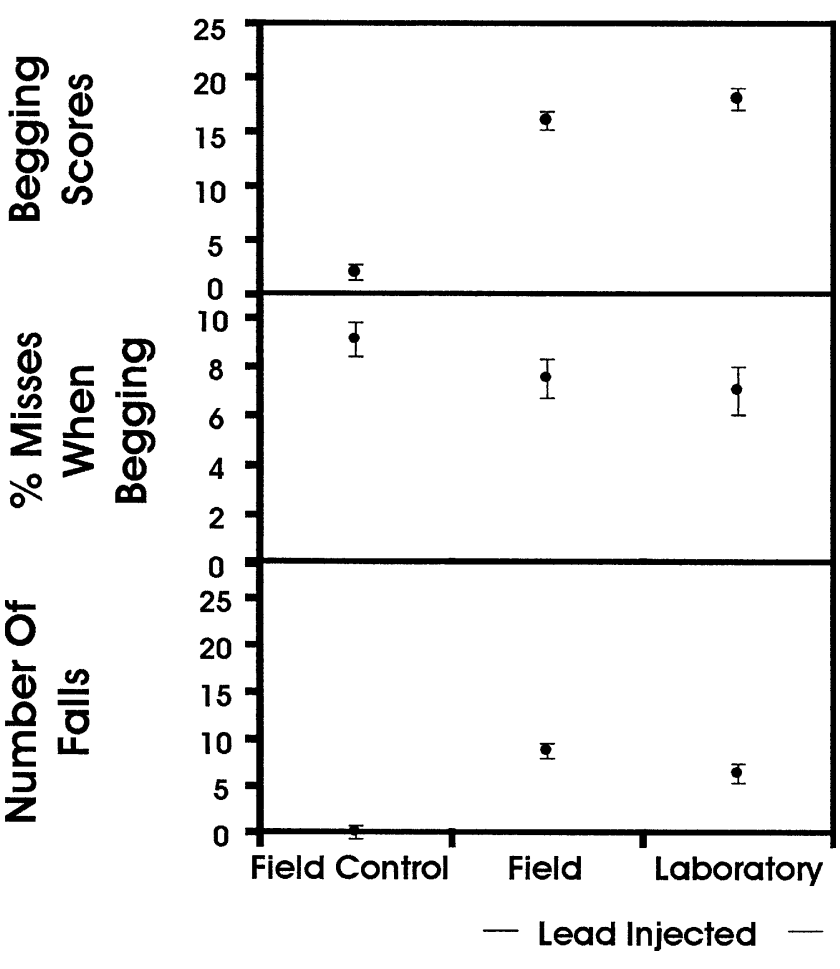

Figure 2. Comparison of behavior for herring gull (Larus argentatus) chicks exposed to lead in the field and laboratory, with field controls (modified from Burger and Gochfeld, 1997a, 2001a).

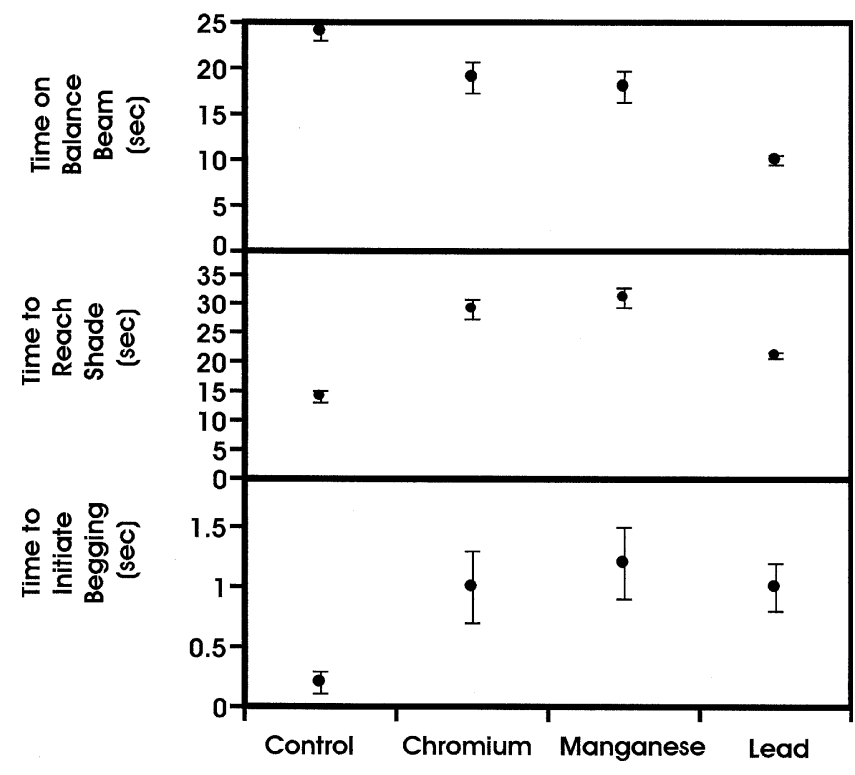

Figure 3. Comparison of neurobehavioral deficits caused by chromium, manganese, and lead (as well as controls) in herring gulls (modified from Burger and Gochfeld, 2001a).

For example, recognition is more severely affected when chicks are exposed at 2-4 days, than when exposed at 12 days, not surprising since individual recognition has 
Sooty Tern (a)

Shearwater (a)

Brown Noddy (a)

Sooty Tern (a)

Brown Noddy (a)

Shearwater (a)

Red-footed Booby (a)

Brown Booby (a)

Sooty Tern (a)

Brown Noddy (a)

Black Noddy (a)

Gannet

Sooty Shearwater

Common Tern (y)

Common Tern (a)

Roseate Tern ( $y$ )

Roseate Tern (a)

Black Skimmer $(y)$

Black Skimmer (a)

Herring Gull (y)

Black Skimmer (a)

Herring Gull (y)

Black Skimmer (y)

Great Black-back (y)

Common Tern (y)

Herring Gull

Herring Gull (control)

(lead injected)

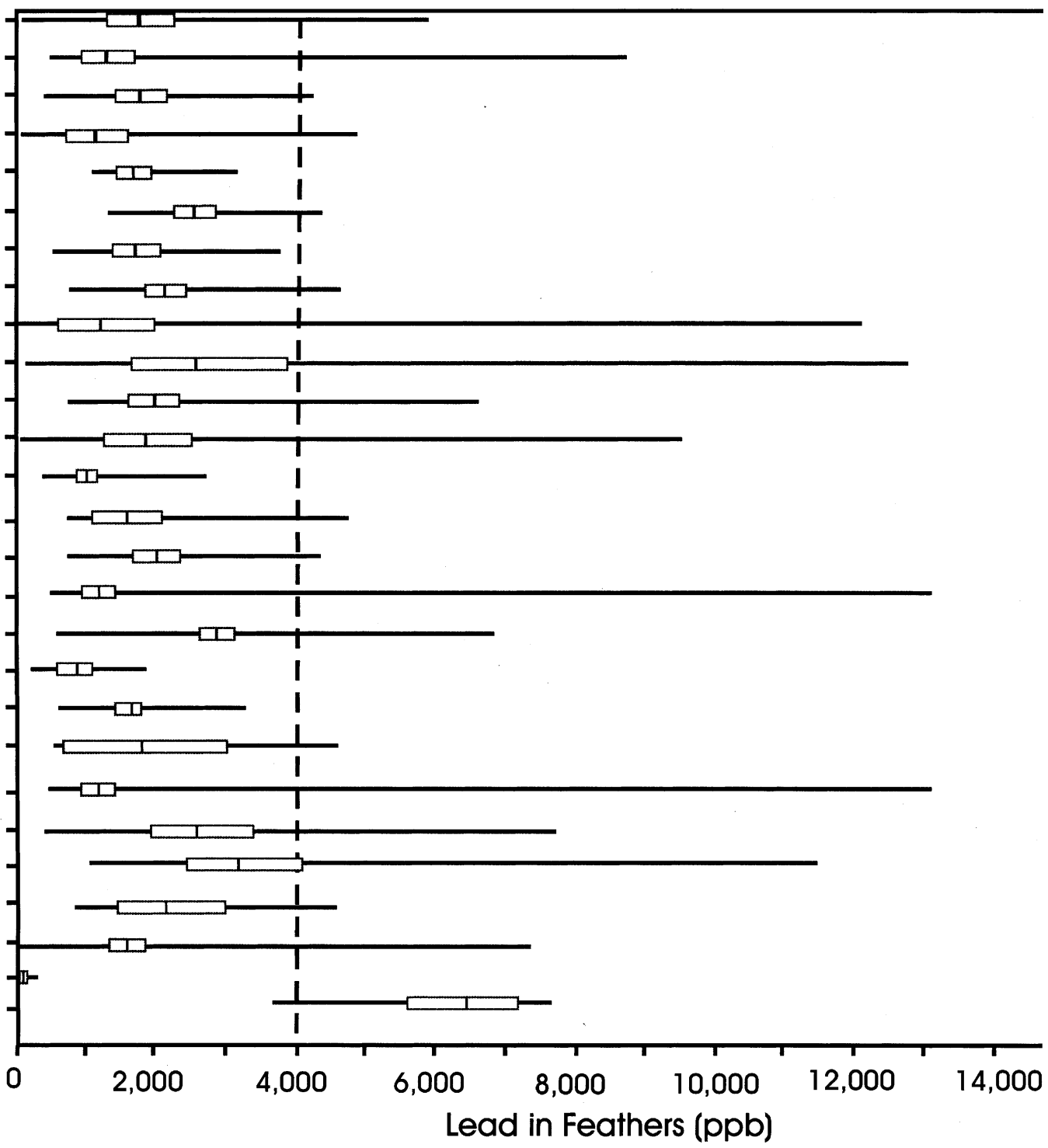

Figure 4. Levels of lead in feathers of birds from around the world, showing adverse effects level (dashed line; after Burger and Gochfeld, 1997a,b [and unpublished data]).

developed by this age. Delayed recognition can be lethal in nature because once chicks begin to move away from their nests they can be attacked and killed by neighbors if they approach a gull other than their parent. Similar effects occur in the laboratory and the field, although the intensity may vary (Fig. 2; Burger and Gochfeld, 1994). Without continued exposure, there is recovery of some behaviors (Burger and Gochfeld, 1995a,b). Finally, parents have some mechanisms to partly ameliorate the adverse effects of lead (Burger and Gochfeld, 1996b). Parents split the brood, and one parent fed the behaviorally impaired chick separately. The lead-exposed chick in each brood was less able to compete for food with its aggressive siblings, and, by feeding it separately, it allowed the chick to obtain enough food.

In the mid-1980s, lead poisoning due to ingestion of lead paint from buildings was reported for Laysan albatross (Diomedea immutabilis) chicks from Midway Atoll (Sileo and Fefer, 1987; Sileo et al., 1990). Albatross chicks spend 5 months at the nest, where they eat nearby small objects, which can include paint chips (Whittow, 1993). Some albatross chicks that hatched near buildings exhibited clinical signs that included drooping wings, weight loss, and death. Paint chips with up to 144,000 ppm lead were found in the proventriculus of affected chicks, and paint chips with up to $247,250 \mathrm{ppm}$ lead and $101 \mathrm{ppm}$ mercury 


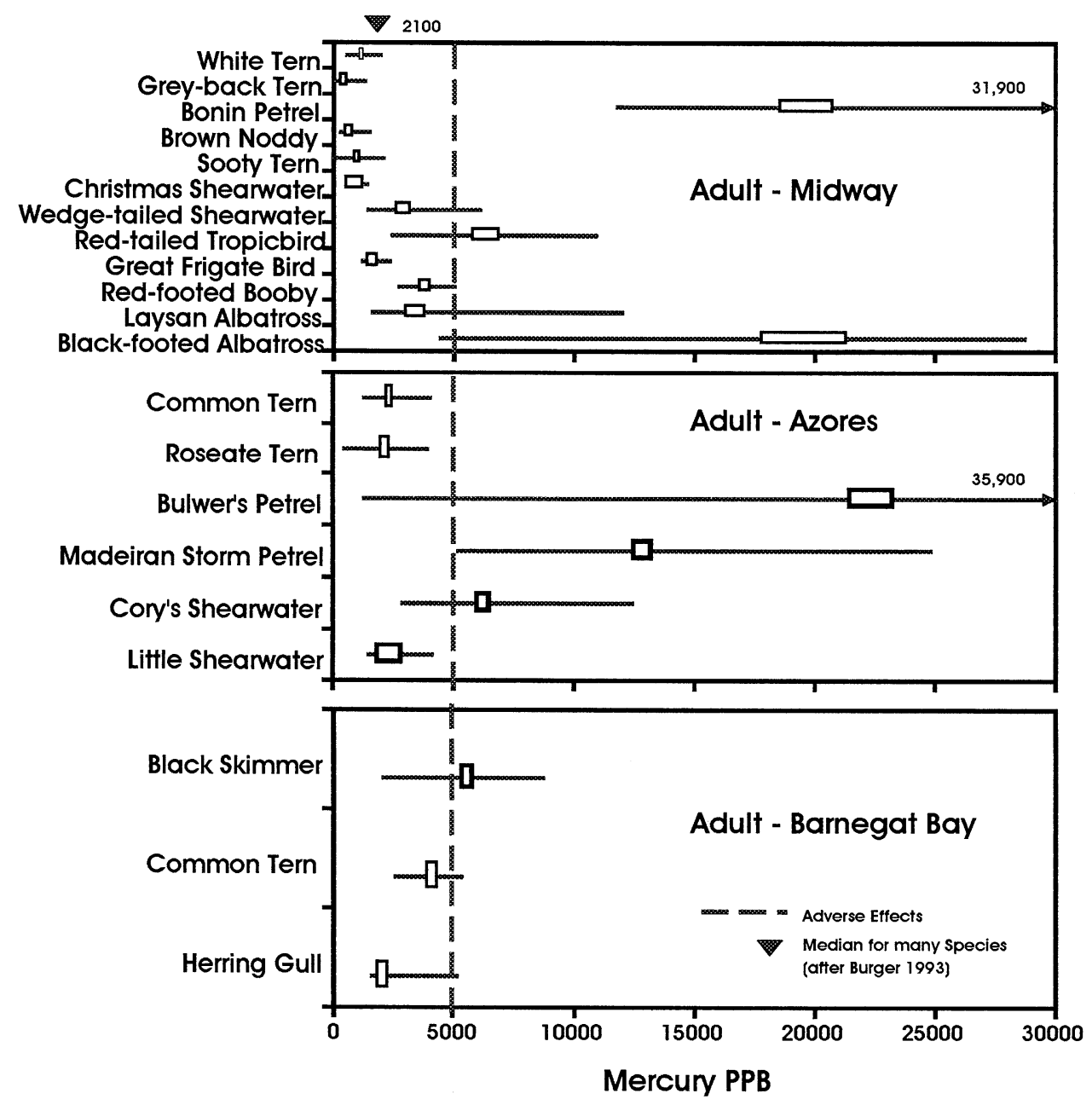

Figure 5. Levels of mercury in feathers of adult seabirds from Barnegat Bay, New Jersey [unpublished data], Midway Atoll (Burger and Gochfeld, 2000c), and the Azores (Monteiro et al., 1998). Dashed line is the effects level. were found at the buildings (Sileo and Fefer, 1987). In 1997, Laysan albatross chicks were still dying from lead poisoning (Burger and Gochfeld, 2000b,c).

The behavioral abnormalities demonstrated in the laboratory and the field with lead also occurred when chicks were exposed to chromium and manganese (Fig. 3; Burger and Gochfeld, 1995c). Although knowledge about these metals is limited, they have a significant potential for toxicity in seabirds. Similarly, tin, used in organotin compounds, is an important potential toxicant for seabirds; yet very little experimental work has been conducted, and there are even fewer field studies that report tin levels.

\section{Tissue Level Studies}

Lead

As part of a monitoring program to understand the global pattern of lead levels, researchers have been measuring lead in feathers since the 1970s. Using the effects level deter- mined from laboratory studies (6500 ppb in feathers), it is possible to examine whether birds from particular regions have exposures that are associated with adverse effects (Fig. 4; after Burger and Gochfeld, 1997a). In general, most birds examined do not have lead levels above the effects level but, in several populations, some individuals have levels higher than the effects level. Furthermore, data collected can be used to indicate whether lead exposure is increasing or decreasing. The data from 2000 from Barnegat Bay indicate lower lead levels than generally found in Long Island from the early 1990s (Burger and Gochfeld, 1997a).

\section{Mercury}

Local levels of mercury in soil and water are a result of natural processes, local anthropogenic emissions, and global atmospheric transport. Natural sources of mercury from erosion, natural flooding, volcanism, and upwellings 


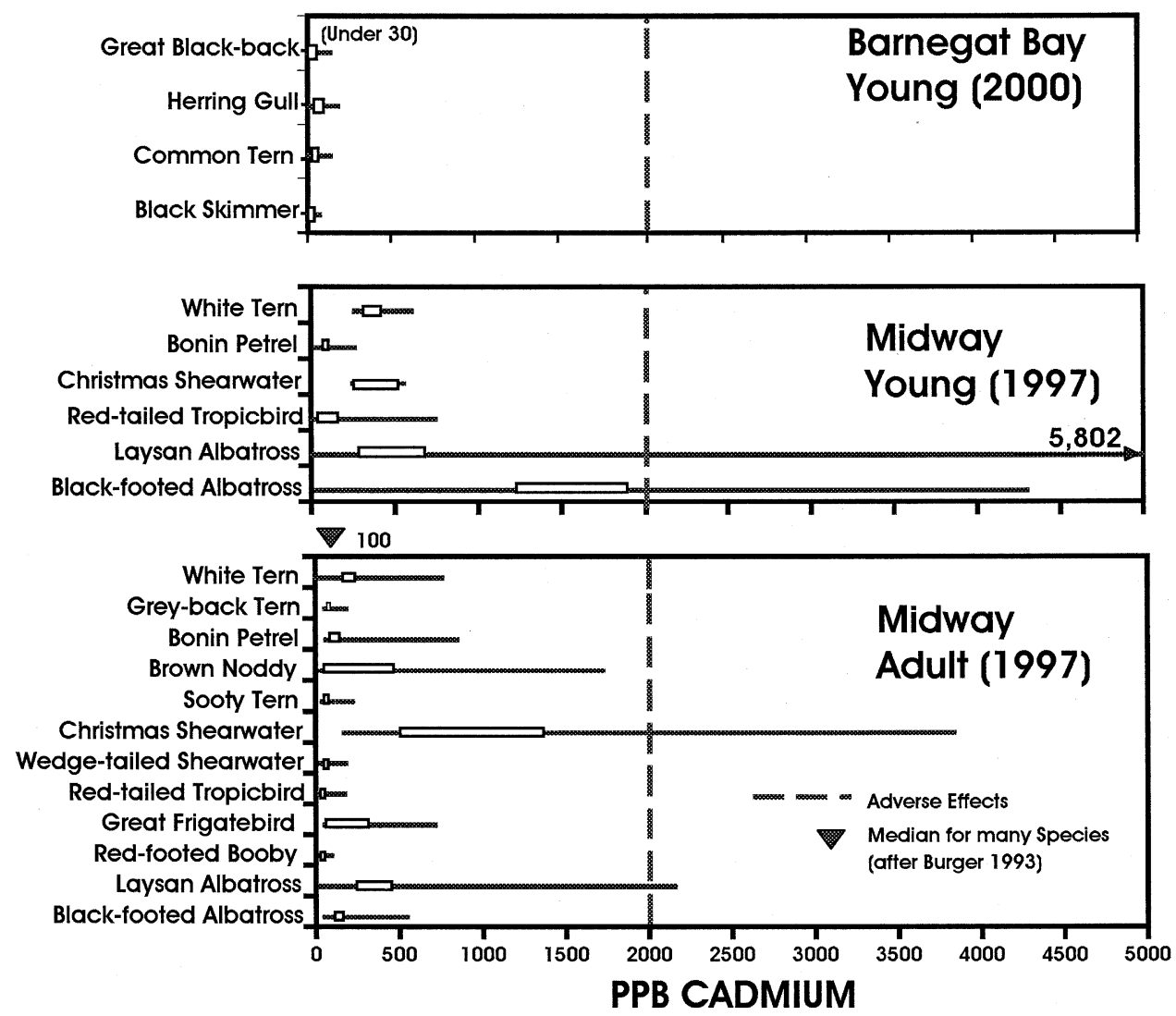

Figure 6. Levels of cadmium in feathers of young and adult seabirds from Midway Atoll (after Burger and Gochfeld, 2000c) and young from Barnegat Bay [Burger, unpublished data]. Dashed line is the effects level. are dwarfed by anthropogenic sources (WHO, 1990; Wren et al., 1995). Mercury is present in elemental, inorganic, and organic forms. Methylmercury, the most toxic form, is the prime contaminant to which seabirds are exposed, because it is preferentially accumulated in tissues of fish and other prey (Nisbet, 1994). Inorganic mercury can be converted into methylmercury by some organisms, particularly anaerobic bacteria, and higher organisms can both produce and demethylate methylmercury (Jensen and Jernelov, 1969). Most studies measure only total mercury. However, in studies that analyze methyl and inorganic mercury separately, methylmercury makes up more than $90 \%$ of the total mercury in liver, kidney, muscle, and feathers of birds (Thompson and Furness, 1989b; but see Thompson et al., 1991). Some seabirds seem able to demethylate mercury and store inorganic mercury in the liver, but most of the mercury in feathers is methylmercury (Thompson and Furness, 1989a,b).

Mercury levels of $5000 \mathrm{ppb}$ in feathers are associated with adverse effects (Eisler, 1987). The mercury concentrations in the adults of several seabird species are above the effect level (Fig. 5, after Burger and Gochfeld, 2000c, 2001a), while the sample of several fish-eating birds from Barnegat Bay is mostly below this level [Burger, unpub- lished data]. It is more difficult to interpret the levels found in adults (compared to young) because many species migrate from the breeding colony. Nonetheless, it is useful because species that might be particularly at risk can be identified. For example, in comparing adult seabirds from Midway, the Azores, and Barnegat Bay (Fig. 5), it is clear that bonin petrel (Pterodroma hypoleuca) from Midway, and several species from the Azores are in the range suggesting further study. Remarkably, black skimmers (Rynchops niger) from Barnegat Bay are also in that range, and their populations are declining in the region (Burger, 2002). Such comparisons are invaluable if we are to use seabirds as sentinels of ecosystem health because it provides ways to identify not only the species at risk, but the species that would be useful as bioindicators.

\section{Cadmium}

In addition to lead and mercury, cadmium is of concern for marine ecosystems (Fowler, 1990). Anthropogenic sources include smelters, and the manufacturing and disposal of commercial products such as batteries, paints, and plastic stabilizers (Furness, 1996). Moreover, agricultural applications of fertilizers can increase cadmium levels 
Table 2. Metals in Marine Birds ${ }^{\mathrm{a}}$

\begin{tabular}{|c|c|c|c|c|c|c|c|c|c|}
\hline & \multicolumn{3}{|c|}{ Mercury } & \multicolumn{3}{|c|}{ Cadmium } & \multicolumn{3}{|l|}{ Lead } \\
\hline & $\begin{array}{l}\text { Data } \\
\text { sets }\end{array}$ & $\begin{array}{l}\text { Median } \\
\text { of means }\end{array}$ & $\begin{array}{l}\text { Range } \\
\text { of means }\end{array}$ & $\begin{array}{l}\text { Data } \\
\text { sets }\end{array}$ & $\begin{array}{l}\text { Median } \\
\text { of means }\end{array}$ & $\begin{array}{l}\text { Range } \\
\text { of means }\end{array}$ & $\begin{array}{l}\text { Data } \\
\text { sets }\end{array}$ & $\begin{array}{l}\text { Median } \\
\text { of means }\end{array}$ & $\begin{array}{l}\text { Range } \\
\text { of means }\end{array}$ \\
\hline Penguins & 4 & 2.5 & $0.2-1700$ & 3 & 0.2 & $0.1-0.4$ & 3 & 0.28 & ND-1.7 \\
\hline Albatrosses & 32 & 6.9 & $1.6-40$ & 24 & 0.47 & $0.05-2.5$ & 24 & $0.97^{\mathrm{b}}$ & $0.2-3.1$ \\
\hline Shearwater/petrels & 35 & 2.6 & $0.2-30.7$ & 21 & 0.4 & $0.07-0.95$ & 19 & 1.4 & $0.1-40.8$ \\
\hline Storm petrels & 2 & 6.5 & $0.2-12.9$ & 1 & 1.2 & 1.2 & 1 & 19.2 & 19.2 \\
\hline Boobies & 6 & 3.8 & $2.9-4.5$ & 4 & 0.13 & $0.05-0.22$ & 7 & 1.3 & $0.82-3.13$ \\
\hline Cormorants & 6 & 3.2 & $0.4-22$ & 3 & 0.3 & $0.2-0.96$ & 3 & 1.9 & $1.0-2.2$ \\
\hline Frigatebirds/tropicbirds & 3 & 2.5 & $1.7-6.4$ & 3 & 2.4 & $1.7-3.5$ & 3 & 0.68 & $0.63-1.5$ \\
\hline Gulls & 76 & 1.7 & $0.2-32$ & 38 & 0.22 & $0.08-1.2$ & 43 & 2.23 & $0.17-25.8$ \\
\hline Terns & 44 & 2.3 & $0.1-12.9$ & 35 & 0.13 & $0.03-1.25$ & 38 & 1.38 & $0.1-4.35$ \\
\hline Skimmers & 4 & 0.2 & $0.1-14.4$ & 3 & 0.13 & $0.06-0.18$ & 4 & 1.6 & $0.8-4.1$ \\
\hline Skuas & 7 & 6.8 & $1.3-8.1$ & 0 & - & - & 0 & - & - \\
\hline Auks & 9 & 3.8 & $1.2-9.2$ & 0 & - & - & 0 & - & - \\
\hline
\end{tabular}

ND, nondetectable.

${ }^{a}$ Modified from Burger and Gochfeld, 2001a [plus unpublished data].

${ }^{\mathrm{b}}$ Mean for albatrosses with diagnosed lead poisoning was 40.2 .

(McLaughlin et al., 1996). Volcanic action is the major natural source of atmospheric cadmium. Other natural sources include ocean spray, forest fires, and releases of particles from terrestrial vegetation (Hutton, 1987). Compared to other organisms, cadmium levels are often relatively high in marine organisms, including seabirds (Furness, 1996).

Cadmium can also be examined by comparing levels found in feathers with those known to cause adverse effects in the laboratory (Fig. 6, after Burger and Gochfeld, 2000c). It is useful to compare young seabirds because they obtain all their cadmium either from the egg during development, or from parents, who in turn feed in the area around the colony. Albatross young on Midway Atoll and possibly some shearwater adults are the exceptions.

\section{Comparative Approach}

For some metals, there are no data that examine the doses that result in adverse effects, or that examine the tissue levels associated with these effects in each group of seabirds. Other than epidemiological studies that indicate adverse effects in a population that are associated with the presence of a given contaminant, there is little recourse to understand contaminant levels. Further, there is variation in tolerance levels within families of birds. Another method is to compare the levels found in an area of interest with those found from a series of studies in the group of birds of interest. Table 2 provides the median levels of mercury, cadmium, and lead found in different groups of seabirds. As is clear, some species generally have higher levels of mercury (e.g., albatrosses, petrels, skuas) than others (e.g., skimmers); similar differences occur for other metals. By comparing the levels in birds found in a local area with those generally reported for the species group, managers and conservationists can determine whether the levels they observe are within the normal range, or at the high end, and whether impacts on individual birds or populations should be anticipated.

\section{Future Research}

The above examples indicate that seabirds have been used extensively as sentinels of environmental contamination. They serve as critical early warning indicators, providing information regarding environmental pollution levels and the effects of chemicals, linking laboratory and field studies. Ideally, we need examples in which effects are identified with tissue and dose levels (Fig. 1). That is, we need examples in which the tissue levels associated with specific effects from different metals are known so that they can be 
used to predict potential effects from levels identified in tissues of wild populations. Then, routine monitoring programs of tissue levels, in some cases noninvasive (hair or feathers), can be used to establish trends and provide a warning before there is cause for alarm or the situation is nonreversible. This suggests a need for more extensive laboratory experimentation with a variety of contaminants to close the link from dose and effect to tissue levels. Moreover, these experiments should include intergenerational studies (e.g., Heinz, 1979), sublethal effects (Burger and Gochfeld, 1997a), and the use of nontraditional species. Many studies in the past were conducted with short-lived species that were easy to keep in the laboratory, and were often not at the top of the food chain. While it is easier to maintain such species in the laboratory, they do not provide an indication of the potential adverse effects on all components of the ecosystem. The adverse effects of DDT were not predicted partly because top-level predators were not examined.

There is also a need to develop noninvasive techniques for sampling for organochlorines, as is possible with metals (from feathers or hair). Another critical need is to design field experiments to ascertain the relationship between laboratory-induced effects and those that will occur in wild populations. Our studies with lead (Burger and Gochfeld, 2000a) provide such an example, but there are many other field experiments that are possible where the parents would continue to care for and feed the chicks natural foods. In some cases, parents could be provisioned with contaminated food of known concentration to feed young.

There is a need for laboratory studies with mixtures of chemicals. We may understand the effect of lead or mercury on development, but not of the combination. Likewise, we often examine the effect of polychlorinated biphenyls (PCBs) or another organochloride alone, but not in combination with a heavy metal. Early studies of contaminant levels in common terns with developmental defects demonstrated elevated levels of mercury (Gochfeld, 1971) and PCBs (Hays and Risebrough, 1972), leading to the suggestion of a synergistic effect (Gochfeld, 1975). Yet these studies were not continued. Indeed, animals in the wild are in most cases exposed to mixtures. Whether such chemicals are additive, subtractive, or synergistic is generally unknown, although some metals have a protective effect on others (e.g., selenium on mercury; Ganther et al., 1972).

Finally, there is a need to develop and refine marine birds (and guilds of seabirds) that can serve as sentinels of ecosystem health, and that provide early warning indicators for human exposure. By carefully selecting marine birds that forage on the same fish (and shellfish), and the same size fish, as people eat, it is possible to develop bioindicators for both ecological receptors and humans (Burger and Gochfeld, 2001b).

Seabirds are useful as sentinel species of ecosystem health because they are often at the top of the food chain, are adapted to marine environments where they have been exposed to pollutants through natural exposure, are sometimes sufficiently common for experimentation, and are of interest to managers, conservationists, and the general public. They can be used to provide early warning of potential exposure for humans that live in the same ecosystems, and often eat the same foods.

\section{ACKNOWLEDGMENTS}

We acknowledge valuable discussions with many colleagues over the years, including K. Cooper, D. Cory-Slechta, B.D. Goldstein, G. Fox, R. Furness, M. Gilbertson, H. Hayes, J. Jehl Jr., K. King, B.G. Murray, I. Nisbet, C. Powers, C. Safina, J. Saliva, B.A. Schreiber, and J. Spendelow. We thank C. Dixon, C. Jeitner, T. Shukla, S. Shukla, and M. McMahon for laboratory assistance, and R. Ramos for graphics. Research has been funded by NIMH, NIEHS (ESO 5022), EPA, the Consortium for Risk Evaluation with Stakeholder Participation (CRESP) through the Department of Energy cooperative agreement (AI\# DE-FC0195EW55084, DE-FG 26-OONT 40938), the New Jersey Department of Environmental Protection (Endangered and Nongame Species Program, Office of Science and Research), Penn Foundation, and the Environmental and Occupational Health Sciences Institute.

\section{REFERENCES}

Anderson DW, Gress F (1983) Status of a northern population of California brown pelican. Condor 83:79-88

Berg W, Johnels A, Sjostrand B, Westermark T (1966) Mercury content in Swedish birds from the past 100 years. Oikos 17:71-83

Beyer WN, Heinz GH, Redmon-Norwood AW (editors) (1996) Environmental Contaminants in Wildlife: Interpreting Tissue Concentrations, SETAC Special Publication Series, Boca Raton, FL: Lewis Publishers

Blus LJ, Cromartie E, McNease L, Joanen T (1979) Brown pelican: population status, reproductive success, and organochlorine residues in Louisiana, 1971-1976. Bulletin of Environmental Contamination and Toxicology 22:128-135

Burger J (1990) Behavioral effects of early postnatal lead exposure in herring gulls (Larus argentatus) chicks. Pharmacology, Biochemistry and Behavior 35:7-13 
Burger J (1993) Metals in avian feathers: bioindicators of environmental pollution. Reviews of Environmental Toxicology 5:203-311

Burger J (1995) A risk assessment for lead in birds. Journal of Toxicology and Environmental Health 45:369-396

Burger J (2002) Food chain differences affect heavy metals in birds in Barnegat Bay, New Jersey. Environmental Research 90:33-39

Burger J, Gochfeld M (1994) Behavioral impairments of leadinjected young herring gulls in nature. Fundamentals of Applied Toxicology 23:553-561

Burger J, Gochfeld M (1995a) Behavior effects of lead exposure on different days for gull (Larus argentatus) chicks. Pharmacology, Biochemistry and Behavior 50:97-105

Burger J, Gochfeld M (1995b) Effects of varying temporal exposure to lead on behavioral development in herring gull (Larus argentatus) chicks. Pharmacology, Biochemistry and Behavior 52:601-608

Burger J, Gochfeld M (1995c) Growth and behavioral effects of early postnatal chromium and manganese exposure in herring gull (Larus argentatus) chicks. Pharmacology, Biochemistry and Behavior 50:601-612

Burger J, Gochfeld M (1996a) Ecological and human health risk assessment: a comparison. In: Interconnections between Human and Ecosystem Health, DiGuilio RT, Monosson E (editors), London: Chapman \& Hall, pp 127-148

Burger J, Gochfeld M (1996b) Lead and behavioral development: parental compensation for behaviorally impaired chicks. Pharmacology, Biochemistry and Behavior 55:339-349

Burger J, Gochfeld M (1997a) Lead and neurobehavioral development in gulls: a model for understanding effects in the laboratory and the field. NeuroToxicology 18:279-287

Burger J, Gochfeld M (1997b) Risk, mercury levels, and birds: relating adverse laboratory effects to field biomonitoring. Environmental Research 75:160-172

Burger J, Gochfeld M (2000a) Effects of lead on larids: a review of laboratory and field studies. Journal of Toxicology and Environmental Health Part B 3:59-78

Burger J, Gochfeld M (2000b) Metals in Laysan Albatross from Midway Atoll. Archives of Environmental Contamination and Toxicology 38:254-259

Burger J, Gochfeld M (2000c) Metal levels in feathers of 12 species of seabirds from Midway Atoll in the northern Pacific Ocean. The Science of the Total Environment 257:37-52

Burger J, Gochfeld M (2001a) Effects of chemicals and pollution on seabirds. In: Biology of Marine Birds, Schreiber EA, Burger J (editors), Boca Raton, FL: CRC Press, pp 485-525

Burger J, Gochfeld M (2001b) On developing bioindicators for human and ecological health. Environmental Monitoring and Assessment 66:23-46

Burger J, Parsons K, Wartenberg D, Safina C, O'Connor J, Gochfeld M (1994) Biomonitoring using least terns, common terns and black skimmers in the northeastern United States. Journal of Coastal Research 19:39-47

Croxall JP, Evans PGH, Schreiber RW (1984) Status and conservation of the world's seabirds. ICBP Technical Publication No. 2, Cambridge, UK

Eisler R (1987) Mercury hazards to fish, wildlife, and invertebrates: a synoptic review. Biological Report 85 (1.10), Washington, DC: U.S. Fish and Wildlife Service

Eisler R (1988) Lead hazards to fish, wildlife, and invertebrates: a synoptic review. Biological Reports 85 (1.14), Washington, DC: U.S. Fish and Wildlife Service
Fisher HI, Fisher ML (1969) The visits of Laysan albatrosses to the breeding colony. Micronesica 5:173-221

Fitzgerald WF (1989) Atmospheric and oceanic cycling of mercury. In: Chemical Oceanography, Volume 10, Riley JP, Chester R (editors), New York: Academic Press, pp 151-186

Fowler SW (1990) Critical review of selected heavy metal and chlorinated hydrocarbon concentrations in the marine environment. Marine Environmental Research 29:1-64

Fox GA (1976) Eggshell quality: its ecological and physiological significance in a DDE-contaminated common tern populations. Wilson Bulletin 88:459-477

Fox GA (1992) Epidemiological and pathobiological evidence of contaminant-induced alterations in sexual development in freeliving wildlife. In: Chemically-induced Alterations in Sexual and Functional Development: the Wildlife/Human Connection, Colborn T, Clement C (editors), Princeton, NJ: Princeton Scientific, pp 147-158

Fry DM, Toone CK, Speich SM, Peard RJ (1987) Sex ratio skew and breeding patterns of gulls: demographic and toxicological considerations. Studies in Avion Biology 10:26-43

Furness RW (1993) Birds as monitors of pollutants. In: Birds as Monitors of Environmental Change, Furness RW, Greenwood JJD (editors), London: Chapman \& Hall, pp 86-143

Furness RW (1996) Cadmium in birds. In: Environmental Contaminants in Wildlife: Interpreting Tissue Concentrations, Beyer WN, Heinz GH, Redmon-Norwood AW (editors), SETAC Special Publication Series, Boca Raton, FL: Lewis Publishers, pp 389-404

Furness RW, Camphuysen KCJ (1997) Seabirds as monitors of the marine environment. ICES Journal of Marine Science 54:726-723

Furness RW, Rainbow PS (editors) (1990) Heavy Metals in the Marine Environment, Boca Raton, FL: CRC Press

Ganther HE, Goudie C, Sunde ML, Kopecky MJ, Wagner R, SangHwang OH, et al. (1972) Selenium relation to decreased toxicity of methylmercury added to diets containing tuna. Science 72:1122-1124

Gochfeld M (1971) Premature feather loss - a new disease of common terns. Kingbird 21:206-211

Gochfeld M (1975) Developmental defects of common terns of western Long Island, New York. Auk 92:58-65

Gochfeld M (1980) Mercury levels in some seabirds of the Humboldt Current, Peru. Environmental Pollution A 22:197-205

Hays H, Risebrough RW (1972) Pollutant concentrations in abnormal young terns from Long Island Sound. Auk 89:19-35

Heinz G (1979) Methylmercury: reproductive and behavioral effects of three generations of mallard ducks. Journal of Wildlife Management 43:394-401

Hoffman DJ, Rice CP, Kubiak TJ (1996) PCBs and dioxins in birds. In: Environmental Contaminants in Wildlife: Interpreting Tissue Concentrations, Beyer WN, Heinz GH, Redmon-Norwood AW (editors), Boca Raton, FL: Lewis Publishers, pp 165-208

Houghton JT, Callander BA, Varney SK (1992) Climate Change 1992, Cambridge, UK: Cambridge University Press

Hutton M (1987) Cadmium. In: Lead, Mercury, Cadmium and Arsenic in the Environment, Hutchinson TC, Meema KM (editors), Chichester, UK: John Wiley \& Sons, pp 35-42

Jensen S, Jernelov A (1969) Biological methylation of mercury in aquatic organisms. Nature 223:753-754

McLaughlin MJ, Tiler KG, Naidu R, Stevens DP (1996) Review: the behaviour and environmental impact of contaminants in fertilizers. Australian Journal of Soil Research 34:1-54 
Mineau P, Fox GA, Norstrom RJ, Weseloh DV, Hallet DJ, Ellenton JA (1984) Using the herring gull to monitor levels and effects of organochlorine contamination in the Canadian Great Lakes. Advances in Environmental and Science Technology 14:425-452

Monteiro LR, Furness RW (1995) Seabirds as monitors of mercury in the marine environment. Water, Air, and Soil Pollution 80:831-870

Monteiro LR, Granadeiro JP, Furness RW (1998) Relationship between mercury levels and diet in Azores seabirds. Marine Ecology Progress Series 166:259-265

National Research Council (NRC) (1999) Hormonally-Active Agents in the Environment, Washington, DC: National Academy Press

Nisbet ICT (1994) Effects of pollution on marine birds. In: Seabirds on Islands: Threats, Case Studies, and Action Plans, Nettleship DN, Burger J, Gochfeld M (editors), Cambridge, UK: BirdLife International, pp 8-25

Peakall DB (1992) Animal Biomarkers as Pollution Indicators, London: Chapman \& Hall

Pekarik C, Weseloh DV (1998) Organochlorine contaminants in herring gull eggs from the Great Lakes 1974-1995: change point regression analysis and short-term regression. Environmental Monitoring and Assessment 53:77-115

Risebrough RW (1986) Pesticides and bird populations. Current Ornithology 3:397-427

Sileo L, Fefer SI (1987) Paint chip poisoning of Laysan albatross at Midway Atoll. Journal of Wildlife Diseases 23:432-437

Sileo L, Sievert PR, Samuel MD (1990) Causes of mortality of albatross chicks at Midway Atoll. Journal of Wildlife Diseases 23:432-437

Thompson DR, Furness RW (1989a) The chemical form of mercury stores in South Atlantic seabirds. Environmental Pollution 60:305-317
Thompson DR, Furness RW (1989b) Comparison of the levels of total and organic mercury in seabird feathers. Marine Pollution Bulletin 20:577-579

Thompson DR, Hamer KC, Furness RW (1991) Mercury accumulation in great skuas Catharacta skua of known age and sex and its effects upon breeding and survival. Journal of Applied Ecology 28:672-684

Thompson DR, Furness RW, Walsh PM (1992) Historical changes in mercury concentrations in the marine ecosystem of the north and north-east Atlantic Ocean as indicated by seabird feathers. Journal of Applied Ecology 29:79-84

Walsh PM (1990) The use of seabirds as monitors of heavy metals in the marine environment. In: Heavy Metals in the Marine Environment, Furness RW, Rainbow PS (editors), Boca Raton, FL: CRC Press, pp 183-204

Weimerskirch H (1997) Foraging strategies of Indian Ocean albatrosses and their relationships with fisheries. In: $A l$ batross Biology and Conservation, Robertson G, Gales R (editors), Chipping Norton, UK: Surren Beatty and Sons, pp 168-179

Weseloh DV, Ewin PJ, Struger J, Mineau P, Bishop CA, Postupalsy S, et al. (1995) Double-crested cormorants of the Great Lakes: changes in population size, breeding distribution and reproductive output between 1913 and 1991. Colonial Waterbirds 18 (Special Publication 1) pp 48-59

Whittow GC (1993) Laysan Albatross (Diomedea immutabilis). Birds of North America 66:1-20

World Health Organization (WHO) (1990) Methylmercury, Geneva: World Health Organization

Wren CD, Harris S, Harttrup N (1995) Ecotoxicology of mercury and cadmium. In: Handbook of Ecotoxicology, Hoffman DJ, Rattner BA, Burton GA Jr, Cairns J Jr (editors), Boca Raton, FL: Lewis Publishers, pp 392-423 